\title{
PENERAPAN METODE DISKUSI BERBASIS MAKALAH PADA MATA KULIAH UMUM BAHASA INDONESIA PROGRAM STUDI EKONOMI SYARIAH
}

\author{
Ferdinan \\ (Sekolah Tinggi Ilmu Agama Islam Auliaurrasyidin Tembilahan)
}

\begin{abstract}
Abstrak
Penelitian ini bertujuan untuk mengetahui dan mendeskripsikan cara dan tujuan penerapan metode diskusi berbasis makalah pada Mata Kuliah Umum Bahasa Indonesia program studi Ekonomi Syariah. Jenis penelitian ini adalah penelitian kualitatif.dengan metode deskriptif. Penelitian ini, dimaksudkan untuk menggambarkan sejelas- jelasnya tentang objek yang diteliti, serta menggambarkan data secara keseluruhan, sistematis, dan akurat tentang penerapan metode diskusi berbasis makalah pada Mata Kuliah Umum Bahasa Indonesia program studi Ekonomi Syariah. Hasil penelitian menunjukkan, bahwa penerapan metode diskusi berbasis makalah pada Mata Kuliah Umum Bahasa Indonesia program studi Ekonomi Syariah dapat meningkatkan kemampuan mahasiswa dalam teknik menulis ilmiah, dapat meminimalisasikan kesalahan berbahasa, dan dapat meningkatkan kemampuan bertanya mahasiswa.
\end{abstract}

Kata Kunci: penerapan, metode diskusi kelompok, berbasis makalah

\section{A. Pendahuluan}

Pendidikan merupakan kunci utama dalam mengembangkan sumber daya manusia. Pendidikan sebagai pondasi mengembangkan sumber daya manusia memerlukan pembaharuan-pembaharuan sesuai dengan tuntutan zaman. Pendidikan mempunyai tugas untuk mengembangkan potensi dan kemampuan manusia secara optimal dan utuh sehingga dapat memberikan manfaat yang seluas-luasnya bagi manusia bersangkutan, bangsa, dan negara. Demikian pula dengan mahasiswa, upaya menggali dan 
mengembangkan potensi kemampuan mahasiswa secara optimal, merupakan tanggung jawab orang tua (keluarga), sekolah dan masyarakat.

Salah satu lembaga pendidikan formal sebagai wadah yang dapat untuk menggali, mengembangkan potensi, dan meningkatkan mutu pendidikan adalah tingkat perguruan tinngi.

Pada perguruan tinggi satu di antara mata kuliah yang disajikan adalah Mata Kuliah Umum Bahasa Indonesia. Tujuan khusus Mata Kuliah Umum Bahasa Indonesia di perguruan tinggi adalah agar para mahasiswa, calon sarjana, terampil menggunakan bahasa Indonesia dengan baik dan benar secara lisan dan terutama secara tertulis sebagai sarana pengungkapan gagasan ilmiah. Adapun tujuan untuk keperluan mahasiswa pada akhir kuliah bahasa Indonesia adalah; (a) agar mahasiswa mampu menyusun sebuah karya ilmiah sederhana dalam bentuk dan isi yang baik dengan menggunakan bahasa Indonesia yang baik dan benar dan (b) agar para mahasiswa memanfaatkan keterampilan dalam berbahasa Indonesia untuk mengembangkan diri sepanjang hayat sehingga terampil menyusun proposal penelitian, laporan penelitian, dan karya ilmiah yang lain, serta sanggup menyusun skripsi sebagai persyaratan mengikuti ujian sarjana.

Merujuk muatan materi yang disajikan sebagai pokok bahasan dan sub pokok bahasan dengan alokasi waktu yang tersedia yaitu, 2x50 menit dengan bobot 2 SKS, serta tujuan perkuliahan umum bahasa Indonesia, menurut penulis sangatlah sarat dan belum berimbang.

Dosen memegang peranan penting dalam upaya menggali, mengembangkan potensi mahasiswa dalam perkuliahan. Dosen seharusnya dapat menciptakan suasana pembelajaran yang membahagiakan sesuai dengan UU RI No. 20 tahun 2003, Pasal 40 butir 2 yaitu: Pendidik dan tenaga kependidikan berkewajiban: 
1. Menciptakan suasana pendidikan yang bermakna, menyenangkan, kreatif, dinamis dan dialogis.

2. Mempunyai komitmen secara profesional untuk meningkatkan mutu pendidikan.

Berangkat dari pengalaman penulis dalam mengajar Mata Kuliah Umum Bahasa Indonesia ditemukan beberapa kecenderungan, di mana kemampuan mahasiswa bertanya dan menjawab dalam berdiskusi/kelompok masih rendah seperti.

Pertama, pada umumnya setiap kelompok/audien hanya menerima copyian dari lembaran pembahasanya saja dari setiap kelompok penyaji. Kedua, rata-rata mahasiswa yang bertanya atau menjawab hanya sekitar 3 sampai 4 orang mahasiswa saja (7\% dari 40 orang mahasiswa). Mahasiswa yang mengajukan pertanyaan tersebut adalah mahasiswa yang sama, sementara sebagian besar mahasiswa yang lain kurang berpartisipasi dalam kegiatan belajar. Ketiga, penulis temukan lagi di lokal adalah mahasiswa yang bertanya tersebut, pertanyaannya itu kurang berbobot atau berkualiatas yang penting dalam diri mahasiswa itu dia ikut berbicara atau bertanya. Mahasiswa yang bertanya tersebut tidak memikirkan apakah pertanyaannya itu berkualitas. Misalkan, mahasiswa bertanya sering menggunakan katakata apakah tetapi jarang sekali menggunakan kata-kata bagaimana. Keempat, masih banyak ditemukan kesalahan-kesalahan dari segi penulisan makalah ilmiah mahasiswa. Kesalahan-kesalahan tersebut terdapat pada bagian awal makalah; cover makalah, penempatan kata pada bagian kata pengantar, dan terdapat juga tidak menggunakan daftar isi makalah. Kemudian, pada bagian inti makalah; tidak menggunakan fungsi paragraph (pragraf pembuka, paragraph transisi. 
Suhardan (2010: 67) meyebutkan bahwa mengajar pada dasarnya adalah merupakan:

Kegiatan akademik yang berupa interaksi komunikasi antara pendidik dan peserta didik. Aktivitas mengajar merupakan kegiatan guru dalam mengaktifkan proses belajar peserta didik dengan menggunakan berbagai metode. Selanjutnya, Suhardan mengemukakan bahwa mengajar efektif merupakan sebuah tindakan guru yang berlatih dalam melaksanakan pekerjaannya, yaitu kemahiran dalam menyajikan bahan pelajaran dengan meramu berbagai penggunaan metode mengajar untuk menyajikan materi belajar.

Secara umum, strategi dapat diartikan sebagai suatu upaya yang dilakukan oleh seseorang atau organisasi untuk sampai pada tujuan. Dalam Kamus Besar Bahasa Indonesia (2008: 1340), "strategi adalah rencana yang cermat mengenai kegiatan untuk mencapai sasaran khusus (yang diinginkan). Hamdani (2011: 18), "strategi adalah suatu prosedur yang digunakan untuk memberikan suasana yang konduktif kepada siswa dalam rangka mencapai tujuan pembelajaran”.

Model pembelajaran kooperatif adalah model pembelajaran dengan setting kelompok-kelompok kecil dengan memperhatikan keberagaman anggota kelompok sebagai wadah siswa untuk bekerjasama dan memecahkan suatu masalah melalui interaksi sosial dengan teman sebayanya, memberikan kesempatan pada peserta didik untuk mempelajari sesuatu dengan baik pada waktu yang bersamaan dan ia menjadi narasumber bagi teman yang lain. Model pembelajaran kooperatif menurut Hamdani, (2010: 165) adalah: 
Merupakan model pembelajaran dengan menggunakan sistem pengelompokan/tim kecil, yaitu antara 4-6 orang yang mempunyai latar belakang kamampuan akademik, jenis kelamin, ras atau suku yang berbeda (heterogen). Sistem penilaian dilakukan terhadap kelompok. setiap kelompok akan memperoleh penghargaan (reward), jika kelompok mampu menunjukkan prestasi yang dipersyaratkan.

Langkah-langkah Model Pembelajaran Kooperatif

\begin{tabular}{|c|l|l|}
\hline Langkah & \multicolumn{1}{|c|}{ Indikator } & \multicolumn{1}{c|}{ Kegiatan Guru } \\
\hline $\begin{array}{c}\text { Langkah } \\
1\end{array}$ & $\begin{array}{l}\text { Menyampaikan tujuan dan } \\
\text { memotivasi siswa. }\end{array}$ & $\begin{array}{l}\text { Guru menyampaikan tujuan pembelajaran } \\
\text { dan mengkomunikasikan kompetensi dasar } \\
\text { yang akan dicapai serta memotivasi siswa. }\end{array}$ \\
\hline $\begin{array}{c}\text { Langkah } \\
2\end{array}$ & Menyajikan informasi & Guru menyajikan informasi kepada siswa \\
\hline $\begin{array}{c}\text { Langkah } \\
3\end{array}$ & $\begin{array}{l}\text { Mengorganisasikan siswa ke } \\
\text { dalam kelompok-kelompok } \\
\text { belajar }\end{array}$ & $\begin{array}{l}\text { Guru menginformasikan pengelompokan } \\
\text { siswa }\end{array}$ \\
\hline $\begin{array}{c}\text { Langkah } \\
4\end{array}$ & Membimbing kelompok belajar & $\begin{array}{l}\text { Guru memotivasi serta memfasilitasi kerja } \\
\text { siswa dalam kelompok-kelompok belajar }\end{array}$ \\
\hline $\begin{array}{c}\text { Langkah } \\
5\end{array}$ & Evaluasi & $\begin{array}{l}\text { Guru mengevaluasi hasil belajar tentang } \\
\text { materi pembelajaran yang telah } \\
\text { dilaksanakan }\end{array}$ \\
\hline $\begin{array}{c}\text { Langkah } \\
6\end{array}$ & Memberikan penghargaan & $\begin{array}{l}\text { Guru memberi penghargaan hasil belajar } \\
\text { individual dan kelompok. }\end{array}$ \\
\hline
\end{tabular}

Menurut Usman (2005) diskusi kelompok merupakan suatu proses yang teratur yang melibatkan sekelompok orang dalam interaksi tatap muka yang informal dengan berbagai pengalaman atau informasi, pengambilan kesimpulan atau pemecahan masalah (Jurnal LPPM Universitas Riau 155 168).

\section{a. Pengertian Makalah}

Faizah (2009: 80) Makalah adalah salah satu bagian dari karya tulis ilmiah, yang menyajikan permasalahan dan pembahasan. Pembahasanya berdasarkan data di lapangan atau kepustakaan yang bersifat empiris dan objektif. Makalah ditulis menurut metodologi penulisan yang baik dan 
benar. Makalah menyajikan pembahasannya berdasarkan data di lapangan yang bersifat empiris-objektif dan masalah dengan melalui proses berpikir deduktif atau induktif.

b. Kerangka Isi Makalah

Faizah (2009: 83), secara umum kerangka isi makalah ilmiah terdiri atas: Bagian awal atau halaman sampul, berisikan tentang judul makalah, untuk apa makalah dibuat, nama penulis makalah, nama lembaga, ucapan terima kasih, daftar isi, dan daftar tabel dan serta daftar gambar (jika ada). Bagian inti atau pendahuluan, berisikan latar belakang, masalah atau topik pembahasan, tujuan penulisan, dan penutup, berisikan kesimpulan dan saran-saran jika dianggap perlu. Bagian akhir, berisikan daftar pustaka/daftar rujukan dan lampiran (jika ada).

c. Pedoman Penulisan Makalah

Faizah (2009: 88-97), pedoman penulisan makalah ilmiah adalah sebagai berikut:

1) Naskah merupakan hasil penelitian atau kajian pustaka yang belum pernah dipublikasikan.

2) Naskah diketik dengan kertas ukuran kuarto (A4) dengan jenis huruf Times New Roman. Ukuran huruf untuk judul 12pt ditebalkan (hitamkan), 11pt tebal untuk nama penulis, 10pt untuk nama dan alamat lembaga, huruf kapital 11pt tebal untuk kata ABSTRAK, 10 pt untuk isi abstrak dan isi pokok naskah, dan huruf kapital 11pt tebal untuk judul pasal-pasal. Tebal makalah lengkap 12- 15, idealnya 12 halaman.

3) Naskah yang berupa hasil penelitian disusun dengan sistematika: (1) Judul, (2) nama penulis,(3) nama lembaga, disertai alamat, (4) abstrak, kata-kata kunci, (5) pendahuluan,(6) rumusan masalah, (7) tujuan (8) tinjuan pustaka (Dasar Teori), (9) metode penelitian, (10) 
hasil dan pembahasan, (11) ucapan terima kasih, jika ada, (12) kesimpulan dan saran, (13) daftar pustaka.

d. Penomoran

Dalam memberikan nomor, harus diperhatikan hal-hal yang berikut ini:

1) Romawi Kecil. Penomoran dengan memakai romawi kecil dipakai untuk halaman judul, abstrak, kata pengantar atau prakata, daftar isi, daftar tabel, daftar grafik, daftar singkatan dan lambang.

2) Romawi Besar. Angka romawi besar digunakan untuk menomori tajuk bab (bab pendahuluan, bab teoritis, bab metode dan objek penelitian, bab analisis data, dan bab penutup).

3) Penomoran dengan Angka Arab. Penomoran dengan angka Arab, dimulai bab I sampai dengan daftar pustaka.

4) Letak Penomoran. Setiap penomoran yang bertuliskan dengan huruf kapital, nomor halaman diletakkan atau berada di tengahtengah, sedangkan untuk nomor selanjutnya berada di tepi batas (pias) kanan atas. e) Sistem Penomoran.Sistem penomoran dengan angka arab mempergunakan sistem dijital. Angka terakhir dalam sistem dijital tidak diberikan titik seperti ini:

\subsection{Latar Belakang Masalah.}

Atmazaki (2006: 171), "naskah konseptual untuk jurnal meliputi yaitu: (1) judul, (2) nama dan afiliasi instusi, (3) abstrak dan kata kunci, (4) pendahuluan, (5) rumusan masalah, (6) tujuan penulisan, (7) pembahasan simpulan dan saran, dan (8) daftar pustaka”.

Bertanya merupakan ucapan verbal yang meminta respons dari seseorang yang dikenai. Respons yang diberikan dapat berupa pengetahuan sampai dengan hal-hal yang merupakan hasil pertimbangan. Jadi bertanya merupakan stimulus efektif yang mendorong kemampuan berfikir. (Hasibuan dan Moedjiono, 2006:62). 
Menurut Hamalik (2003:73) teknik bertanya ini untuk meningkatkan kualitas serta kuantitas jawaban siswa, disamping guru harus memperhatikan tiga faktor teknik bertanya yakni:

(1) Teknik menunggu (memberi waktu cukup untuk berfikir)

Berikan waktu sejenak satu sampai lima detik kepada siswa untuk berfikir dalam rangka untuk menentukan jawabannya, memberikan waktu untuk memberikan kesempatan berfikir pada siswa karena hal itu ada efek positifnya misalnya:

(a) Siswa dapat memberikan jawaban yang lebih panjang dan lengkap.

(b) Jawaban siswa lebih analisis dan kreatif

(c) Siswa merasa lebih yakin akan jawabanya.

(d) Partisipasi siswa meningkat.

\section{(2) Teknik reinforcement}

Pemakaian yang tepat dari teknik ini akan menimbulkan sikap yang positif bagi siswa serta meningkatkan partisipasi siswa dalam kegiatan belajar mengajar sehingga memungkinkan pencapaian prestasi belajar tinggi.

(3) Teknik menuntun dan menggali (prompting and probling)

Prompting dan probling questions dapat digunakan teknik untuk meningkatkkan kuantitas dan kualitas jawaban siswa. Probling guestions adalah pertanyaan yang bersifat menggali untuk mendapatkan jawaban yang lebih lanjut dari siswa yang bermaksud mengembangkan kualitas jawaban, sehingga jawaban berikutnya lebih jelas, akurat serta lebih beralasan.

Bertanya juga merupakan proses belajar, proses menambah pengetahuan dan keterampilan tertentu serta dapat mempercepat seseorang mencapai tujuan belajarnya. Sebetulnya, mengajukan pertanyaan tidak susah, asal si penanya memiliki modal pemahaman atas permasalahan yang akan ditanyakan bukan harus mengerti isunya. Dalam kepemimpinan diri 
maupun perusahaan, kemampuan bertanya adalah kemampuan vital yang wajib dimiliki. Setiap ilmuwan dan orang-orang besar selalu mengawali kedahsyatan mereka dengan pertanyaan yang tepat, dan memang, orang sukses memiliki pertanyaan yang lebih berkualitas dari kebanyakan orang. Skill dalam mengajukan pertanyaan berkualitas menjadi sama pentingnya dengan skill dalam memberikan jawaban yang tepat.

Pada penelitian ini peneliti mencoba mencari alternatif pemecahannya dengan menerapkan metode diskusi berbasis makalah yang banyak melibatkan aktivitas mahasiswa yaitu dengan menggunakan metode diskusi berbasis makalah dalam proses pembelajaran. Peneliti berharap dengan menggunakan metode diskusi berbasis makalah ini akan meningkatkan keaktifan mahasiswa dalam belajar, karena adanya unsur kerjasama dalam memecahkan masalah yang ada sehingga mahasiswa terbiasa berpikir dan saling mengeluarkan pendapat, sehingga akan meningkatkan aktivitas bertanya dalam proses belajar mengajar.

Berdasarkan uraian-uraian dari latar belakang di atas, maka penulis tertarik untuk menerapkan suatu konsep pembelajaran Mata Kuliah Umum Bahasa Indonesia yang berjudul “ Penerapan Metode Diskusi Berbasis Makalah Pada Mata Kuliah Umum Bahasa Indonesia Program Studi Ekonomi Syariah”.

\section{B. Metode}

Jenis penelitian ini adalah penelitian kualitatif.dengan metode deskriptif. Penelitian ini, dimaksudkan untuk menggambarkan sejelasjelasnya tentang objek yang diteliti, serta menggambarkan data secara keseluruhan, sistematis, dan akurat tentang tujuan dan penerapan metode diskusi berbasis makalah pada prodi Ekonomi Syahriah Auliaurasydin Tembilahan. Data yang dihasilkan dari penelitian bukanlah angka-angka, 
tetapi berupa kata-kata atau gambaran sesuatu Bogdan dan Bilden (dalam Gani, 2010: 269).

Objek penelitian ini adalah makalah ilmiah mahasiswa Prodi Ekonomi Syahriah pada semester satu dua. Penelitian ini dilaksanakan, untuk mendapatkan data yang benar-benar akurat. Penelitian ini difokuskan pada tujuan dan penerapan metode diskusi berbasis makalah pada prodi Ekonomi Syahriah semester 1 dan 2 STAI Auliaurasydin Tembilahan, oleh karena itu, sebagai informan penelitian ini adalah seluruh mahasiswa prodi Ekonomi Syahriah semester 1 dan 2.

Pada penelitian ini, data diperoleh dengan cara tes, yaitu tes uraian. Tes adalah serentetan pertanyaan atau latihan serta alat lain yang digunakan untuk mengukur keterampilan, pengetahuan inteligensi, kemampuan atau bakat yang dimiliki oleh individu atau kelompok (Arikunto, 2010:193). Oleh karena itu, instrumen yang digunakan dalam penelitian ini ada tiga macam, yaitu peneliti sendiri yang berperan sebagai instrumen kunci, instrumen berupa tes uraian, yaitu petunjuk dan perintah menulis karangan tentang perjalanan, serta instrumen berupa tabel korpus data untuk analisis data.

Teknik analisis data dalam penelitian ini menggunakan empat tahap, yaitu (1) identifikasi, yakni melakukan kegiatan identifikasi kesalahan-kesalahan menulis makalah ilmiah sesuai dengan rumusan masalah kemudian memberi kode pada data yang sudah ditemukan, (2) kategorisasi, yakni melakukan kegiatan pengelompokan data sesuai dengan kategori khusus yang telah ditemukan dari aspek format dan sistematikan penulisan, (3) penyajian data, yakni menampilkan data secara lebih sederhana dalam bentuk tabel dan persentase untuk diinterpretasikan dalam bentuk naratif dan diuraikan kedalam penjelasan sesuai dengan berbagai konsep yang 
terkait dengan hasil analisis, dan (4) penarikan kesimpulan, yakni kegiatan menyimpulkan data yang telah diidentifikasi dan dikategorisasi sesuai dengan rumusan masalah. Keabsahan data digunakan untuk memperoleh data dan kesimpulan yang valid sebagai suatu karya ilmiah. Keabsahan data diperoleh melalui dua teknik, yaitu dengan kegiatan pengecekan ahli dan pengecekan teori.

\section{Hasil dan Pembahasan}

1. Penerapan Metode Diskusi Berbasis Makalah Pada Mata Kuliah Umum Bahasa Indonesia

Berdasarkan teori-teori yang telah diuraikan di atas, penulis mencoba untuk menerapkan model pembelajaran metode diskusi berbasis makalah. Model pembelajaran seperti ini mungkin bisa dikatakan semua pendidik (guru/dosen) menggunakanya dengan cara dan tujuan yang berbeda.

Pada Mata Kuliah Umum Bahasa Indonesia, penerapan model pembelajaran seperti ini penulis merujuk pendapat Atmazaki (2006: 145), "Keilmiahan sebuah makalah mengandung dua unsur penting, yaitu format sistematika penulisan, dan bahasa.

Pelaksanaan penelitian ini dimulai bulan September sampai bulan Oktober 2017 dan bulan Nopember sampai Desember 2017, dengan rincian sebagai berikut.

a. Perencanaan

Sebelum melakukan penelitian/perbaikan langkah-langkah perencanaan tindakan yang akan dilaksanakan sebagai berikut:

1. Mempersiapkan perngkat pembelajaran

2. Menyiapkan instrumen penelitian meliputi lembar observasi, evaluasi dan refleksi.

b. Pelaksanaan Tindakan 
Tahap 1 : Menyiapkan kompetensi dan memotivasi siswa

- Menyampaikan apersepsi, memotivasi kesiapan belajar mahasiswa dan menyampaikan standar kompetensi, kompetensi dasar dan indikator yang ingin disampaikan.

- Mengelompokan mahasiswa secara acak, berdasarkan jumlah pertemuan/tatap muka.

Tahap 2 : Mengorganisasikan mahasiswa untuk belajar

- membagikan lembar kerja dan masing-masing kelompok diberi tugas mendiskusikannya.

- memberikan contoh cara membuat makalah ilmiah sederhana, misalnya

- jumlah halaman maksimal 12-15 halaman kuarto/A-4;

- ditulis dengan jarak 2 spasi, 12 pt, Times New Roman

- sertakan Cover, kata pengantar, daftar isi, daftar pustaka, minimal 5 literatur.

- perhatikan ejaan, kalimat, tanda baca dan kerapihan makalah.

Tahap 3 : Membimbing kerja kelompok atau individual

- Pada tahap ini siswa dalam kelompoknya masingmasing diberi kesempatan untuk berfikir dan mengerjakan tugasnya masing-masing dan dosen berperan membimbing dan mengarahkan mahasiswa sambil melakukan pengamatan dan observasi.

Tahap 4 : Mengembangkan dan menyajikan hasil tugas

- Pada tahap ini dosen meminta setiap kelompok mempresentasikan hasil diskusi dan membacakan hasil yang dibuatnya dengan baik dan benar dan kelompok yang lain menyimak dan menanggapinya. 
- Aturan diskusi dengan alokasi waktu penyajian (2X50 menit).

- Setiap kelompok penyaji menyiapkan satu/dua foto copy

- makalah lengkap untuk setiap kelompok.

- sepuluh menit digunakan dosen untuk; mengucapkan salam, menayakan kabar, absensi, mereview kembali pokok bahasan sebelumnya, menyebutkan aturan berdiskusi, misalnya;

- dalam berdiskusi, moderator menentukan sipenanya dan sipenanya menentukan sipenjawab (diutamakan mahasiswa yang yang kurang/tidak aktif).

- setiap kelompok penyaji mendapat giliran untuk menjawab pertanyaan.

- menentukan kelompok untuk menyakan bagian makalah yang dibahas (awal, inti, dan penutup);

- waktu presentasi (memahami hasil diskusi) $= \pm 10$ menit;

- waktu tanya jawab $= \pm 70$ menit, dengan ketentuan pertanyaan; maksimal ada 3 pertanyaan untuk setiap bagian makalah (awal, inti, dan penutup).

- model pertanyaan tuntas, sehingga tidak ada debat kusir. jawaban singkat, padat dan jelas. Gunakan bahasa Indonesia yang baik dan benar.

Tahap 5 : Menganalisis dan mengevaluasi

- Pada tahap ini, guru mengevaluasi dan melakukan observasi kegiatan siswa dan memberikan refleksi dan komentar terhadap presentasi dan pembacaan hasil diskusi pada masing-masing kelompok. 
2. Tujuan Penerapan Metode Diskusi Berbasis Makalah Pada Mata Kuliah Umum Bahasa Indonesia.

Setiap mata kuliah yang disajikan dalam perkuliahan mempunyai tujuan-tujuan tersendiri yang harus mampu dicapai oleh setiap mahasiswa. Tujuan-tujuanya ini tidak akan sama, tentu tergantung kepada kopetensi mata kuliah masing-masing.

Pada Mata Kuliah Umum Bahasa Indonesia, penggunaan metode seperti ini adalah untuk:

1. membiasakan mahasiswa lebih awal untuk mengetahui taknik penulisan ilmiah;

2. melatih untuk menggabungkan hasil bacaan dari berbagai sumber;

3. mengenalkan dengan kegiatan kepustakaan;

4. meningkatkan pengorganisasian fakta/data secara jelas dan sistematis;

5. memperoleh kepuasan intelektual;

6. memperluas cakrawala ilmu pengetahuan;

7. menumbubuhkan sikap ilmiah mahasiswa, seperti;

a) sikap ingin tahu (bertanya mengapa, apa, dan bagaimana);

b) Sikap kritis (mencari fakta sebanyak mungkin;

c) Sikap terbuka (menerima pendapat orang lain);

d) Sikap objektif (menyatakan apa adanya);

e) Sikap menghargai orang lain (mengutip karangan orang lain dengan mencantumkan nama pengarang);

f) Sikap berani (mempetahankan hasil diskusi).

Setelah diadakan evaluasi hasil pembelajaran pada Mata Kuliah Umum Bahasa Indonesia dapat dipersentasekan sebagai berikut.

Pada indikator mahasiswa yang menunjuk tangan menunjukan peningkatan yang cukup signifikan dan hasilnya cukup memuaskan. Hasil 
partisipasi belajar mahasiswa yang memuaskan tersebut dapat dilihat dari rata-rata persentase indikator mahasiswa yang mengemukakan pertanyaan, siklus I rata-rata persentasenya $27 \%$ dan siklus II $43 \%$. Dilihat dari angka tersebut terjadi peningkatan yang cukup signifikan yaitu $16 \%$. Peningkatan ini terjadi karena rasa keingintahuan mahasiswa tentang materi yang di bahas dalam diskusi.

Pada indikator mahasiswa yang menanggapi pendapat mahasiswa lain pada siklus I 29\% dan siklus II 42\%. Dari penjabaran di atas, terjadi peningkatan yaitu $13 \%$. Peningkatan ini terjadi karena mahasiswa telah di tugasi untuk mencari beberapa buku sumber dan meringkasnya atau buat makalah serta memahami isinya sehingga mereka lebih kritis menanggapi jawaban dari mahasiswa lain.

Indikator mahasiswa yang pertanyaannya berkualitas juga mengalami peningkatan yaitu pada siklus I rata-rata persentasenya $22 \%$ dan pada siklus II $42 \%$. Dari angka tersebut dapat dilihat bahwa terjadi peningkatan yang cukup signifikan yaitu $20 \%$. Peningkatan ini terjadi karena mahasiswa telah mempunyai beberapa buku sumber, dengan itu mahasiswa mempunyai banyak bahan atau materi yang akan di tanyakan dan memahami atau paham dengan materi yang akan di tanyakan.

Sesuai dengan kegiatan tindakan yang telah dilakukan secara keseluruhan aktivitas belajar mahasiswa dalam keterampilan diskusi kelompok mengalami peningkatan. Sesuai dengan tujuan penelitian, maka proses pembelajaran yang berorientasi dan memberdayakan mahasiswa serta pembelajaran yang memfungsikan dosen sebagai fasilitatornya dapat berjalan dengan lancar seperti yang diharapkan sesuai dengan prosedur metode diskusi dan prosedur penelitian ini tentunya.

Hal ini sesuai dengan pendapat Hamalik (1989) bahwa strategi pengajaran adalah keseluruhan metode yang menitik beratkan pada kegiatan 
siswa dalam proses belajar mengajar untuk mencapai tujuan tertentu, sedangkan guru lebih bersifat fasilitator dan pembimbing, dengan demikian, penerapan strategi belajar dengan menggunakan metode diskusi berbasis makalah dapat menciptakan suasana belajar yang komunikatif antara dosenmahasiswa, mahasiswa-dosen dan mahasiswa-mahasiswa sehingga dapat mewujudkan kegiatan pembelajaran yang menyenangkan bagi mahasiswa dan dapat mempermudah tercapainya tujuan dari pembelajaran itu sendiri.

\section{Kesimpulan}

Sesuai dengan analisis data dan pembahasan hasil penelitian tentang metode diskusi berbasis makalah pada mata kuliah Bahasa Indonesia mahasiswa Prodi Ekonomi Syahriah, dapat ditarik beberapa kesimpulan sebagai berikut :

1. Penerapan metode diskusi berbasis makalah sangat membantu mahasiswa dalam memahami Mata Kuliah Umum Bahasa Indonesia agar mahasiswa lebih untuk meningkatkan aktivitas bertanya dalam pembelajaran sehingga dapat berdayaguna efektif dan efisien baik untuk dosen dalam menyampaikan materi maupun bagi mahasiswa menerima materi.

2. Persentase mahasiswa yang menunjuk tangan pada siklus I $49 \%$ siklus II $64 \%$. Hal ini menunjukan terjadinya peningkatan yang cukup signifikan yaitu $15 \%$. Dengan demikian, angka tersebut telah menunjukan bahwa indikator keberhasilan yaitu $\geq 40 \%$ sudah tercapai sesuai dengan apa yang diharapkan.

3. Persentase mahasiswa yang mengemukakan pertanyaan pada siklus I $27 \%$ dan siklus II $43 \%$. Hal ini menunjukan terjadinya peningkatan yang cukup signifikan yaitu 16\%. Dengan demikian, angka tersebut telah 
menunjukan bahwa indikator keberhasilan yaitu $\geq 40 \%$ sudah tercapai sesuai dengan apa yang diharapkan.

4. Persentase menanggapi pendapat mahasiswa lain pada siklus I $29 \%$ dan siklus II $42 \%$. Hal ini menunjukan terjadinya peningkatan yang cukup signifikan yaitu 13\%. Dengan demikian, angka tersebut telah menunjukan bahwa indikator keberhasilan yaitu $\geq 40 \%$ sudah tercapai sesuai dengan apa yang diharapkan.

5. Persentase pertanyaan mahasiswa yang berkualitas pada siklus I $22 \%$ dan siklus II $42 \%$. Hal ini menunjukan terjadinya peningkatan yang cukup signifikan yaitu 20\%. Dengan demikian, angka tersebut telah menunjukan bahwa indikator keberhasilan yaitu $\geq 40 \%$ sudah tercapai sesuai dengan apa yang diharapkan.

\section{E. Saran}

Berdasarkan hasil penelitian dan pembahasan, maka dapat disarankan:

1. Untuk dapat lebih memupuk semangat mahasiswa untuk hadir kuliah di dalam kelas perlu adanya pemberian sanksi baik dari pihak dosen yang bersangkutan maupun dari ketua prodi sebagai pimpinan prodi.

2. Untuk meningkatkan aktivitas bertanya mahasiswa dalam hal indikator mahasiswa yang menunjuk tangan, diperlukan peran aktif dosen dalam memberikan stimulus atau rangsangan agar mahasiswa yang belum bertanya juga ikut bertanya.

3. Untuk meningkatkan aktivitas bertanya mahasiswa dalam hal indikator mahasiswa menunjuk tangan, dosen harus memberikan semangat dan dukungan agar mahasiswa tersebut percaya diri untuk menunjuk tangan dan guru beserta mahasiswa lainnya juga harus menghargai setiap gerakgerik mahasiswa tersebut di dalam kelas. 
4. Untuk meningkatkan aktivitas bertanya dalam hal indikator mahasiswa yang mengemukakan pertanyaan, guru maupun mahasiswa lain harus menghargai setiap pertanyaan yang dikemukakan mahasiswa walaupun pertanyaan tersebut tidak berkualitas. Dalam hal ini diperlukan peran dosen untuk mengontrol sikap dan tingkah laku mahasiswa agar mahasiswa yang mengemukakan pertanyaan tidak merasa pesimis dan takut diejek oleh mahasiswa lain.

5. Untuk meningkatkan aktivitas bertanya mahasiswa dalam hal indikator menanggapi pendapat mahasiswa lain, dosen harus menugaskan mahasiswa agar lebih banyak mencari referensi buku untuk dijadikan pedoman atau acuan agar pengetahuan mahasiswa bertambah sehingga dapat berpikir kritis terhadap pendapat yang dikemukakan oleh mahasiswa lain.

6. Untuk meningkatkan aktivitas bertanya mahasiswa dalam hal indikator pertanyaan mahasiswa yang berkualitas, dosen harus menugaskan mahasiswa agar lebih banyak mencari beberapa buku sumber sehingga pembendaharaan pengetahuan atau lebih memahami materi yang akan didiskusikan agar pertanyaan itu sesuai dengan materi dan berkualitas.

7. Untuk meningkatkan keterampilan bertanya mahasiswa yang lebih baik disarankan kepada dosen geografi menerapkan metode diskusi tersebut dalam pembelajaran.

8. Untuk mahasiswa yang aktivitas bertanya nya masih rendah atau belum pernah bertanya, disarankan kepada PA mahasiswa itu sendiri untuk membantu dosen mata kuliah yang mengalami kesulitan dalam menstimulus mahasiswa yang bersangkutan.

9. Perlunya kerjasama antara dosen, PA, ketua Prodi dan pihak-pihak terkait untuk membantu mensosialisasikan metode diskusi ini dan menyediakan sarana dan prasarana yang dibutuhkan oleh dosen saat 
mengajar proses pembelajaran berjalan dengan baik, lancar dan agar terciptanya suasana belajar yang menyenangkan bagi mahasiswa.

\section{DAFTAR PUSTAKA}

AR, Faizah, Hasnah. 2009. Menulis Karangan Imiah. Pekanbaru: Cendikia Insani Pekanbaru.

Arifin, E dkk. 2006. Cermat Berbahasa Indonesia Untuk Perguruan Tinggi. Jakarta: Akademika Pressiando, 2006.

Atmazaki. 2006. Kiat-Kiat Mengarang dan Menyunting. Padang: Yayasan Citra Budaya Indonesia

Aunurrahman. 2009. Belajar dan Pembelajaran. Bandung: Alfabeta

Arikunto, S. 2010. Prosedur Penelitian: Suatu Pendekatan Praktik. Jakarta: Rineka Cipta.

Bulatau, S. J. 2006. Teknik Diskusi Berkelompok. Yogyakarta: Kanisius.

Buku Panduan. 2011. Penulisan Tesis dan Disertasi. Universitas Negeri Padang. Padang: UNP PRESS.

Buku Panduan.2013. Mata Kuliah Bahasa Indonesia, Direktorat Jenderal Pendidikan Tinggi Kementrian Pendidikan dan Kebudayaan RI.

Ermanto, dkk. 2015. Bahasa Indonesia Pengembangan Kepribadian di Perguruan. Padang: Padang UNP PRESS.

Erni. 2015. "Penggunaan Metode Diskusi untuk Meningkatkan Hasil Belajar Materi Perubahan Sosial pada Siswa Kelas XII SMA Negeri 4 Pekanbaru". Jurnal Sorot. 10 (2) : 155-168

Gani, Erizal. 2010. Pantun Minang Kabau dalam Perspektif Budaya dan Pendidikan.Padang: UNP Press 
Hamdani. 2011. Strategi Belajar Mengajar. Bandung: Pustaka Setia.

Hasibuan dan Moedjiono. 2006. Proses Belajar Mengajar. Bandung: Remaja Rosdakarya.

Hamalik Oemar.2003. Psikologi Pendidikan. Jakarta: Depdikbud

Sardiman.A.M. 1996. Interaksi dan Motivasi Belajar Mengajar. Jakarta: PT. Raja Grafindo Persada.

Sugandi, Achmad, dkk. 2004. Teori Pembelajaran. Semarang: UPT MKK UNNES.

Suhardan, Dadang. 2010. Supervisi Profesional. Bandung: Alfa Beta

Supriyadi. 2011. Strategi Belajar dan Mengajar. Yogyakarta : Cakrawala Ilmu Undang-undang Republik Indonesia No. 20 Tahun 2003 Tentang Pendidikan Nasional sisdiknas, Bandung: Citra Umbara, 2003.

Wiyanto, Asul. 2000. Seri Terampil Diskusi. Jakarta: Grasindo.

Wekarnis dan Hamadi. 2009. Strategi Pembelajaran Berorientasi Standar Proses Pendidikan. Jakarta: Prenada Media Group.

Werkanis 2005. Strategi Pembelajaran Kurikulum Berbasis Kompetensi. Pekanbaru: Riau Persada.

Zarkasi, Firdaus, M. 2009. Belajar Cepat dengan Diskusi. Surabaya: Indah 